\title{
Spectrophotometric Assay of Sulphamethoxazole in Pure and Pharmaceutical Dosage Forms by Diazotization and Coupling Reaction
}

\author{
Salim A. Mohammed \\ Hind A. Zamel \\ Department of Chemistry / College of Science / University of Mosul
}

(Received 19/8/2013;Accepted 28/10/2013)

\begin{abstract}
A simple, rapid, accurate and sensitive spectrophotometric method has been developed for the quantitative determination of sulphamethoxazole (SMX) in both pure form and its pharmaceutical preparations. The proposed method is based on the diazotization of SMX with sodium nitrite in hydrochloric acid medium to form a diazonium salt, which is coupled with $\gamma$-resorsolic acid (2,6-dihydroxybenzoic acid) in alkaline medium of sodium hydroxide to form a stable and watersoluble azo dye exhibited maximum absorption at $432 \mathrm{~nm}$ against reagent blank. Beer's law is obeyed over the concentration range of 5 to $300 \mu \mathrm{g}$ of SMX $/ 20 \mathrm{~mL}(0.25-15 \mathrm{ppm})$ with a good determination coefficient $\left(\mathrm{R}^{2}=0.9984\right)$ and apparent molar absorptivity $3.34 \times 10^{4} 1 . \mathrm{mol}^{-1} \cdot \mathrm{cm}^{-1}$. The limit of detection (LOD) and limit of quantification (LOQ) are 0.0584 and $0.1752 \mu \mathrm{g} \mathrm{mL} \mathrm{m}^{-1}$, respectively. The recoveries and relative standard deviations in tablets and oral suspension formulations are found as 96.6 to $99.04 \%$ and 1.6 to $3.0 \%$, respectively, depending on the concentration level. The method is suitable for the determination of SMX in the presence of other excipients that are usually present in dosage forms. The composition of the resulting product has also been worked out and it is found to be (1:2)SMX: $\gamma$-resorsolic acid. This procedure is applied successfully to the analysis of SMX in pharmaceutical preparations (tablets and oral suspension) without prior separation but with acceptable errors.
\end{abstract}

Keywords: Sulphamethoxazole, Diazotization and Coupling Reaction, $\gamma$-Resorsolic acid, Spectrophotometry

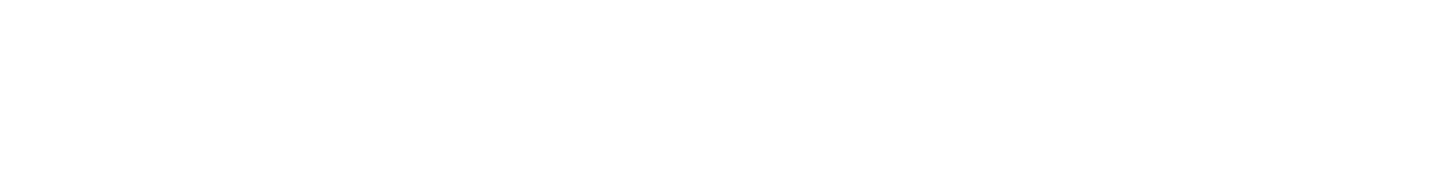

الماdi

طُورتطوريقة طيفية بسطة وسريعة ومسلسة لقندير للسلفميثوكسازول بشكله الحر وفي بعض مستحضراته الصيدلانية. تتضمن الطريقة أزوتة للسفلميثوكسازول بولنطة نتريت الصوديوم وحلمض الهيدروكلوريك ثم اقترانه مع الكلثف ر - حلمض الريسوبسك (6,2 - ثنائي هيدروكسي حلمض البززويك) في محلول قاعدي من هيدروكسيد الصويوم لتكوين صبغة آزوية

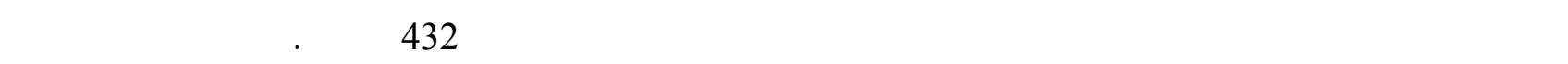

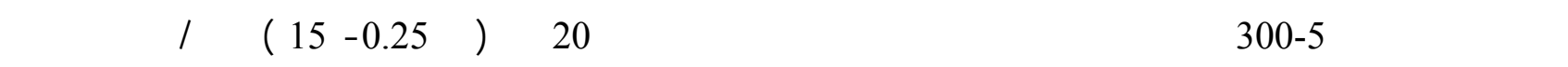

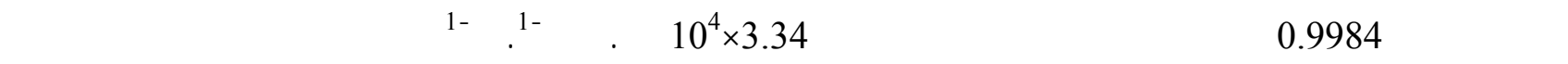

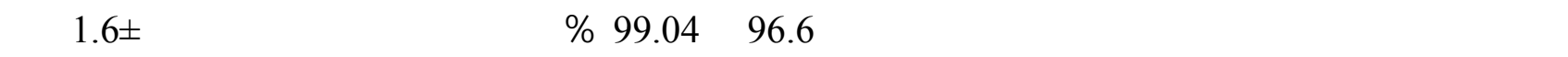

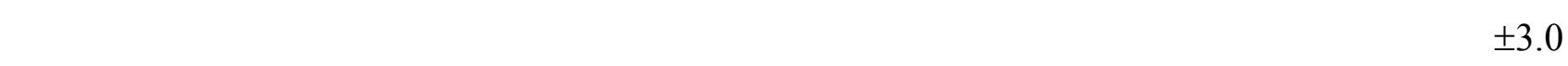
حد الكثف (LOD) وقيمة حد القدير الكمي (LOQ) للطريقة 0.0584 و0.1752 مايكروغرلم. مللتر -1 على التوالمي. وأن 


\section{نسبة الفاعل بين اللسفلميثوكسازول ور - حلمض الريسوبسك هي2 :1، وقدطقت الطاريقة بنجاح لققير للسفلميثوكسازول في الأقراص الدوائية والمحلول المعاق.

\author{
الكالت الدالة:سلفميثوكسازول، ازوتة واقتران، ر- حلمض الريسووسك، قديرطيف.
}

\section{INTRODUCTION}

SMX [4-amino-(5-methyl-3-isoazolyl)benzenesulfonamide], is a sulfonamide bacteriostatic antibiotic (British Pharmacopoeia, 2001). Sulfonamides are structural analogs and competitive antagonists of para-aminobenzoic acid (PABA). They inhibit normal bacterial utilization of PABA for the synthesis of folic acid, an important metabolite in DNA synthesis (Mitscher, 2002). SMX is short to medium acting agents used almost exclusively to treat urinary tract infections, eye infections and as a prophylaxis of rheumatic fever (Petri, 2001). The usual adult dosage is 1g of SMX two or three times daily. The fixed-drug combination of trimethoprim (TMP) - SMX is the drug of choice for infections such as Pneumocystis jiroveci (formerly $\mathrm{P}$ carinii) pneumonia, toxoplasmosis, nocardiosis, and occasionally other bacterial infections (Katzung, 2007).

Various techniques for SMX determination have been described, including the continuous wavelet transform (CWT) spectrophotometric ultraviolet (Alatas and Wulansari ,2008), partial least square regression method (Givlanrad et al., 2013), nuclear magnetic resonance (Salema et al., 2006), micellar electrokinetic capillary chromategraphy (MEKC) (Injac et al., 2008), HPLC (Bedor et al., 2008), square-wave volammetry (Souza et al., 2008), differential pulse voltammetry (DPV) (Joseph and Kumar, 2010), net analyte signal standard addition (Givianrad and Mohagheghian, 2012) and flow injection system /HPLC (Sabriye et al., 2011). However, most of them suggest that the quantification of SMX in any matrix requires elaborate and sophisticated instruments which may or may not be available in every laboratory, others were time consuming as well as the most potentiometric methods used a sulphamethoxazole-selective electrode or other ion-selective electrodes which are either expensive or not readily available in the market, or involve difficult methods of fabrication.

Many UV-Visible spectrophotometric methods have been developed for the determination of SMX. Most of them included diazotization of SMX and then coupling with different coupling agents such as phloroglucinol (Upadhyay et al., 2012), 3-aminophenol (Nagaraja et al., 2007), pyrogallol (Othman, 2005), 2-Naphthol (Shamsa and Amani, 2006), 1-naphthol (Sinan and Al-Uzri, 2011), 8-hydroxyquinoline (Nagaraja et al., 2007), tropaeolin O (Boiko et al., 2011) and resorcinol (Vijaya Raja et al., 2008). Other methods were either based on the formation of charge transfer complex with phenosafranine (Al-Attas, 2003) or Schiff's base reaction with p-dimethylaminobenzaldehyde (Siddappa et al., 2011). Some of these methods suffer from various limitations for example, low stability of the colored product formed, others required heating or extraction (Upadhyay et al., 2012), long time for the reaction to complete (Siddappa et al., 2011), laborious (Al-Attas, 2003), applicable to higher conc- entrations of the drug (Shamsa and Amani, 2006), or not sensitive (Boiko et al., 2011).

In order to overcome the above limitations, it was thought worthwhile to develop a simple, sensitive and accurate spectrophotometric method for the determination of SMX based on the coupling of diazotized SMX with a new coupling agent, $\gamma$-resorsolic acid (2,6-dihydroxybenzoic acid), to form orange colored product in alkaline medium that has been proved successfully for the determination of SMX in both pure form and its pharmaceutical preparations. 


\section{EXPERIMENTAL}

\section{Apparatus}

All absorption spectra and absorbance measurements are carried out on a Shimadzu UV-160 double beam UV-visible spectrophotometer (Japan) with 1.0-cm silica cells. The pH measurements are made with a professional Benchtop $\mathrm{pH}$ meter BP3001.

\section{Reagents}

Sulphamethoxazole solution $(100 \mu \mathrm{g} / \mathrm{mL})$, is prepared by dissolving $0.0100 \mathrm{~g}$ of SMX in $5 \mathrm{~mL}$ of ethanol and the volume is completed to $100 \mathrm{~mL}$ with distilled water in a volumetric flask. Working solution of SMX is prepared by an appropriate dilution of the stock solution with distilled water.

$\gamma$-Resorsolic acid (Fluka) $(0.1 \%$, w/v) solution, is prepared by dissolving $0.1000 \mathrm{~g}$ of $\quad \gamma$ resorsolic acid reagent in $100 \mathrm{~mL}$ distilled water using a volumetric flask. Sodium nitrite (BDH) $(1 \%, \mathrm{w} / \mathrm{v})$ solution is prepared by dissolving $1.000 \mathrm{~g}$ of sodium nitrite in $100 \mathrm{~mL}$ distilled water. Sulfamic acid (Fluka)(3\%, w/v) solution is also prepared.

\section{General procedure and calibration graph}

To 20-Ml calibrated flasks, SMX (10-300 $\mu \mathrm{g})$ and $0.7 \mathrm{~mL}$ of $1 \mathrm{M} \mathrm{HCl}$ are transferred, followed by $0.5 \mathrm{~mL}$ of $1 \%$ sodium nitrite solution. The reaction mixtures are allowed to stand for $1 \mathrm{~min}$, and then $1 \mathrm{~mL}$ of $3 \%$ sulfamic acid is added and mixed thoroughly. After about 2 minutes, $1 \mathrm{~mL}$ of $0.1 \% \gamma$-resorsolic acid solution and $2 \mathrm{~mL}$ of $1 \mathrm{M}$ sodium hydroxide solutions are added. The flasks are kept at room temperature for 1 minute and the contents are diluted to the marks with distilled water and mixed well. The absorbance of the formed azo dye is measured at $432 \mathrm{~nm}$ against the corresponding reagent blank.

\section{Procedure for the assay of pharmaceutical preparations}

For tablets. Ten tablets (each containing $400 \mathrm{mg}$ SMX and $80 \mathrm{mg}$ trimethoprim/tablet) are weighed and crushed to powder. An accurately weighed portion of the powder, equivalent to about $0.0100 \mathrm{~g}$ of SMX is dissolved in $5 \mathrm{~mL}$ of ethanol .The solution is mixed, warmed if necessary and filtered into a $100 \mathrm{~mL}$ volumetric flask. The residue is then washed with $5 \mathrm{~mL}$ of ethanol and the volume is diluted to the mark with distilled water. Each $\mathrm{mL}$ of this solution contains $100 \mu \mathrm{g}$ SMX. For oral suspension, (200 mg SMX and $40 \mathrm{mg}$ trimethoprim $/ 5 \mathrm{~mL})$. A suitable volume $(0.625 \mathrm{~mL})$ of the oral suspension containing about $0.025 \mathrm{~g}$ of SMX is diluted with $5 \mathrm{~mL}$ of ethanol and distilled water. The solution is filtered into $250 \mathrm{~mL}$ volumetric flask, the residue is washed with 5 $\mathrm{mL}$ of ethanol and finally the volume is diluted to the mark with distilled water to obtain a solution containing $100 \mu \mathrm{g} . \mathrm{mL}^{-1}$ of SMX.

\section{RESULTS AND DISCUSSION}

Throughout the preliminary study on the reaction of SMX $\left(100 \mu \mathrm{g} \cdot \mathrm{mL}^{-1}\right)$ with sodium nitrite $(0.5 \mathrm{~mL}$ of $1 \%)$ in hydrochloric acid medium $(1 \mathrm{M})$ and after the removal of the residual nitrite (as nitrous acid) with sulfamic acid (3\%), the formed diazonium salt is then coupled with $\gamma$-resorsolic acid $(1.5 \mathrm{~mL}$ of $0.1 \%)$ in a basic medium (1M), an intensely colored water-soluble azo dye is obtained which showed a maximum absorption at $432 \mathrm{~nm}$ in contrast to the reagent blank ( Fig.1). 


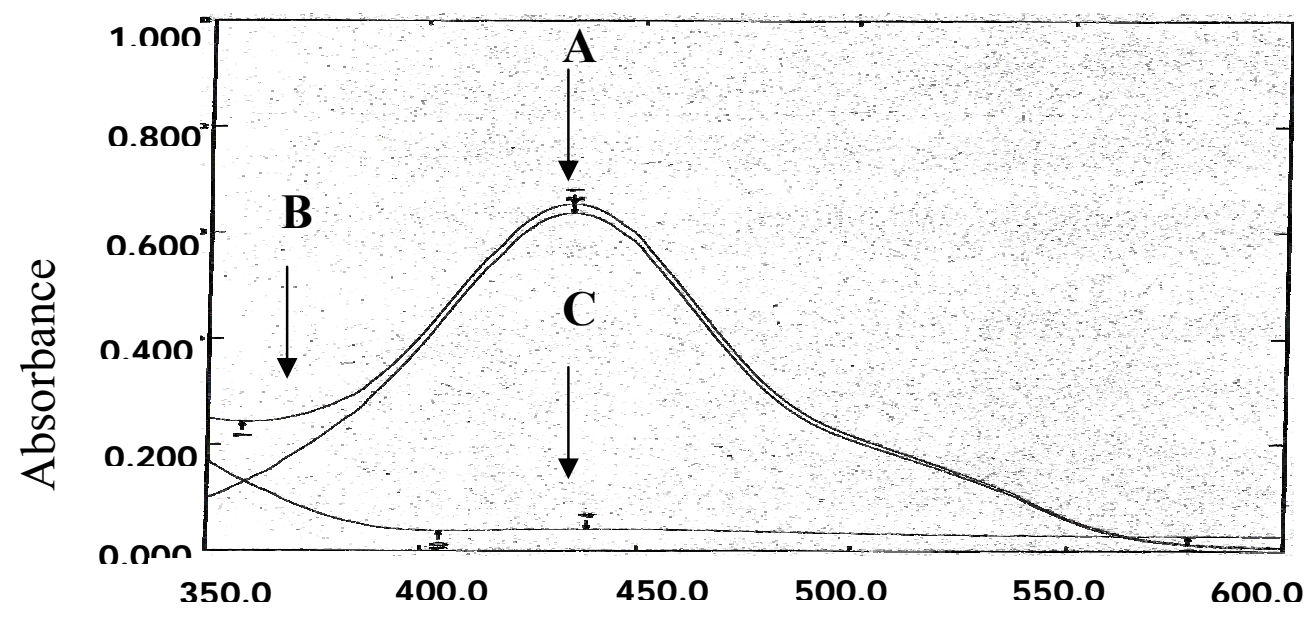

Wavelength, nm

Fig. 1: Absorption spectra of the azo dye against (A) reagent blank (B) distilled water and $(C)$ blank measured against distilled water.

The intensity of the formed dye has been found to be proportional to the amount of SMX originally present in the solution.

The effect of various parameters on the absorption intensity of the colored azo dye is investigated and the optimum reaction conditions have been selected.

The diazotization reaction of SMX takes place in acidic medium. Therefore, the effect of different amounts of various acids $(1 \mathrm{M})$, such as: $\mathrm{HCl}, \mathrm{HNO}_{3}, \mathrm{CH}_{3} \mathrm{COOH}$, and $\mathrm{H}_{2} \mathrm{SO}_{4}$ is studied in diazotization of SMX for the purpose of producing intense colored dye and lower blank value. The results in Fig. 2 show that $0.7 \mathrm{~mL}$ of $1 \mathrm{M} \mathrm{HCl}$ solution is the most suitable acidic medium because it gives high intensity for the dye with corresponding low reagent blank absorbance and is selected for the reaction. It seems that sulphate inhibits the diazotization of SMX.

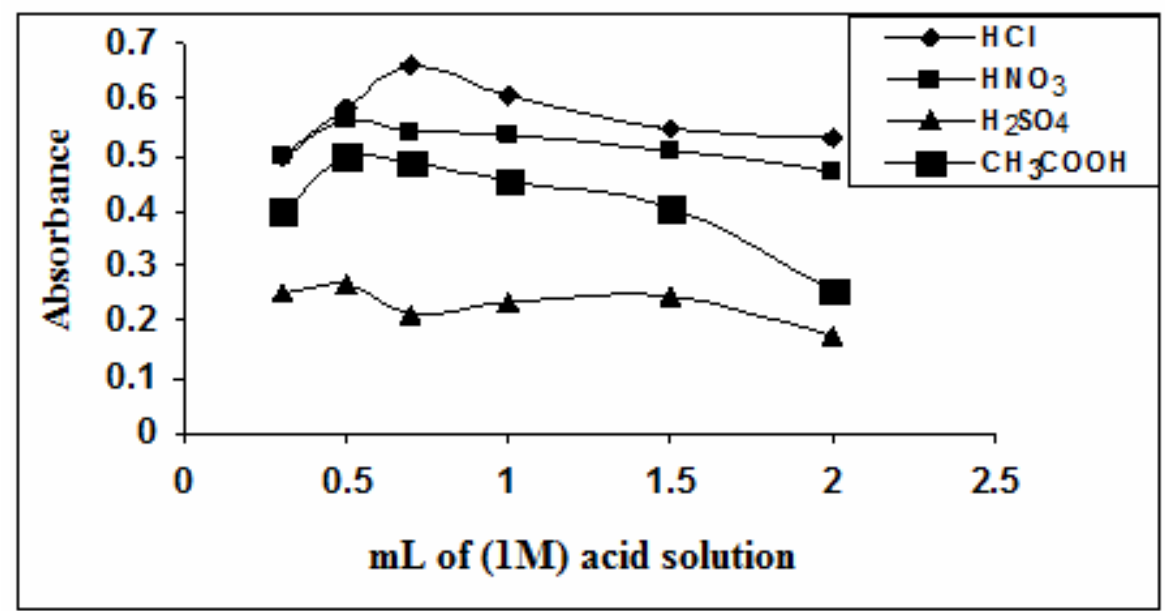

Fig. 2: Effect of different amounts of various acids (1M) on the absorbance of azo dye.

The effect of different amounts $(0.3-0.8 \mathrm{~mL})$ of $1 \%$ sodium nitrite and $(0.3-2 \mathrm{~mL})$ of $3 \%$ sulfamic acid on the absorbance of the resulting azo dye have been also studied. (Figs. 3 and 4) show that $0.5 \mathrm{~mL}$ of $1 \%$ sodium nitrite and $1 \mathrm{~mL}$ of $3 \%$ sulfamic acid solutions are enough to obtain 
the maximum absorbance after about 1 and 2 min as a reaction time for sodium nitrite and sulfamic acid, respectively and they are recommended for all the subsequent experiments.

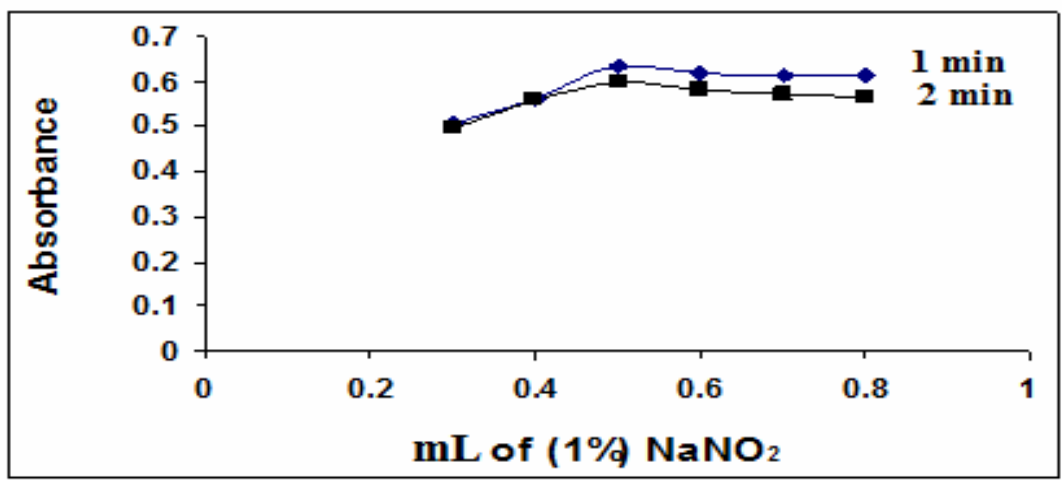

Fig. 3: Effect of the amount of $1 \% \mathrm{NaNO}_{2}$ on the absorbance of azo dye.

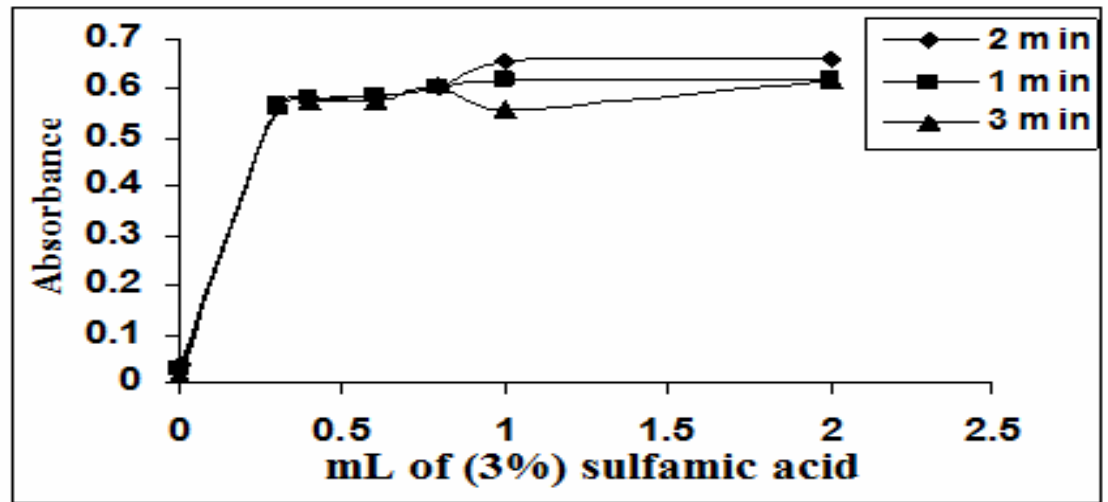

Fig. 4: Effect of the amount of $3 \%$ sulfamic acid solution and time on the absorbance of azo dye.

\section{Effect of $\gamma$-resorsolic acid amount and time}

The effect of $\gamma$-resorsolic acid amount on the absorbance of the azo dye has been studied. The results in (Table 1) indicate that $1 \mathrm{~mL}$ of $0.1 \% \gamma$-resorsolic acid is most suitable to give the highest intensity value for the azo dye.

Table 1: Effect of the amount of $\gamma$-resorsolic acid on the absorbance of azo dye

\begin{tabular}{|c|c|c|c|c|c|c|c|}
\hline \multirow{2}{*}{$\begin{array}{c}\text { mL of } 0.1 \% \\
\text { resorsolic acid- } \gamma \\
\text { solution }\end{array}$} & \multicolumn{6}{|c|}{ Absorbance/ $\mu \mathrm{g}$ of SMX } & \multirow[t]{2}{*}{$\mathbf{R}^{2}$} \\
\hline & 10 & 20 & 30 & 50 & 70 & 100 & \\
\hline 0.5 & 0.089 & 0.146 & 0.229 & 0.339 & 0.464 & 0.662 & 0.9989 \\
\hline 1.0 & 0.097 & 0.158 & 0.231 & 0.354 & 0.487 & 0.698 & 0.9995 \\
\hline 1.5 & 0.093 & 0.151 & 0.230 & 0.349 & 0.491 & 0.692 & 0.9993 \\
\hline 2.0 & 0.092 & 0.149 & 0.230 & 0.350 & 0.488 & 0.687 & 0.9992 \\
\hline
\end{tabular}

\section{Effect of base}

The coupling reaction of diazotized SMX with $\gamma$-resorsolic acid happens in alkaline medium. Therefore, the effect of different amounts $(0.5-4 \mathrm{~mL})$ of $1 \mathrm{M}$ solutions of various bases such as: sodium hydroxide, sodium carbonate, sodium bicarbonate, potassium hydroxide and ammonia have been examined for the purpose of producing intense colored dye with lower blank values. The results in Fig. (5) indicate that sodium carbonate, sodium bicarbonate and ammonia exhibit weak 
color contrast which is apparently due to $\mathrm{pH}$ variation. Therefore, $2 \mathrm{~mL}$ of $1 \mathrm{M}$ sodium hydroxide solution at $(\mathrm{pH}=12.1)$ is recommended for the subsequent experiments.

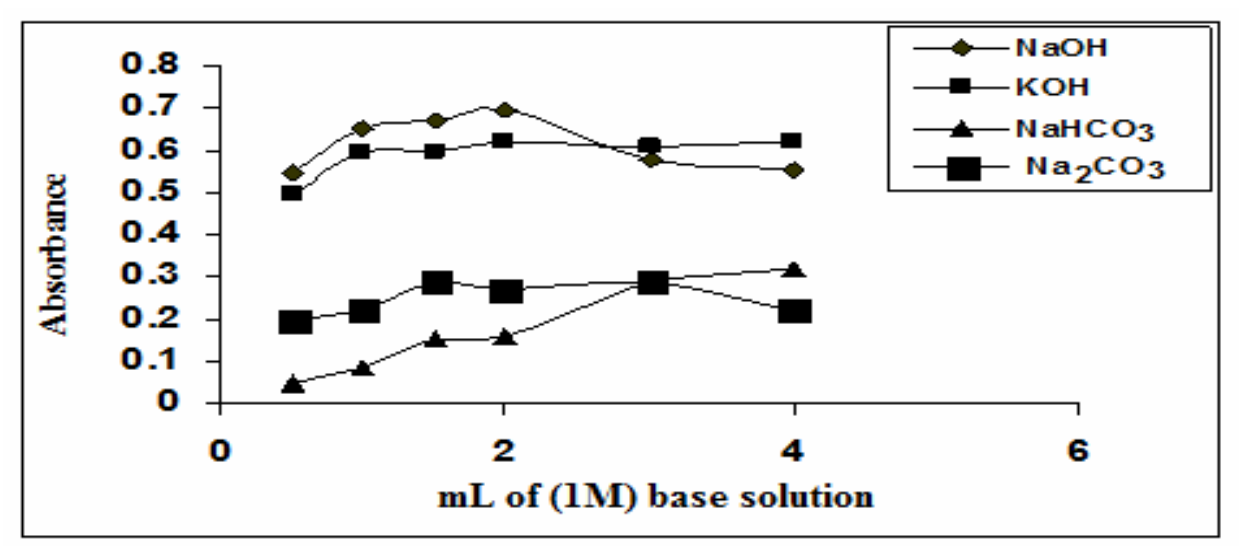

Fig. 5: Effect of different amounts of various bases $(1 \mathrm{M})$ on the absorbance of azo dye.

The development time and stability period on the absorbance of the colored dye at $432 \mathrm{~nm}$ under the optimal experimental conditions have been investigated. The experimental results showed that the colored azo dye developed immediately after mixing for $1 \mathrm{~min}$ and the absorbance remained maximum and constant for at least 60 minutes at room temperature.

\section{Validity of Beer's law and reproducibility}

Under the optimum operating conditions, a linear calibration curve is obtained over the concentration range of 5-300 $\mu \mathrm{g}$ of SMX in a final volume of $20 \mathrm{~mL}$ (i.e., $0.25-15 \mu \mathrm{g} / \mathrm{mL}$ ) (Fig. 6).

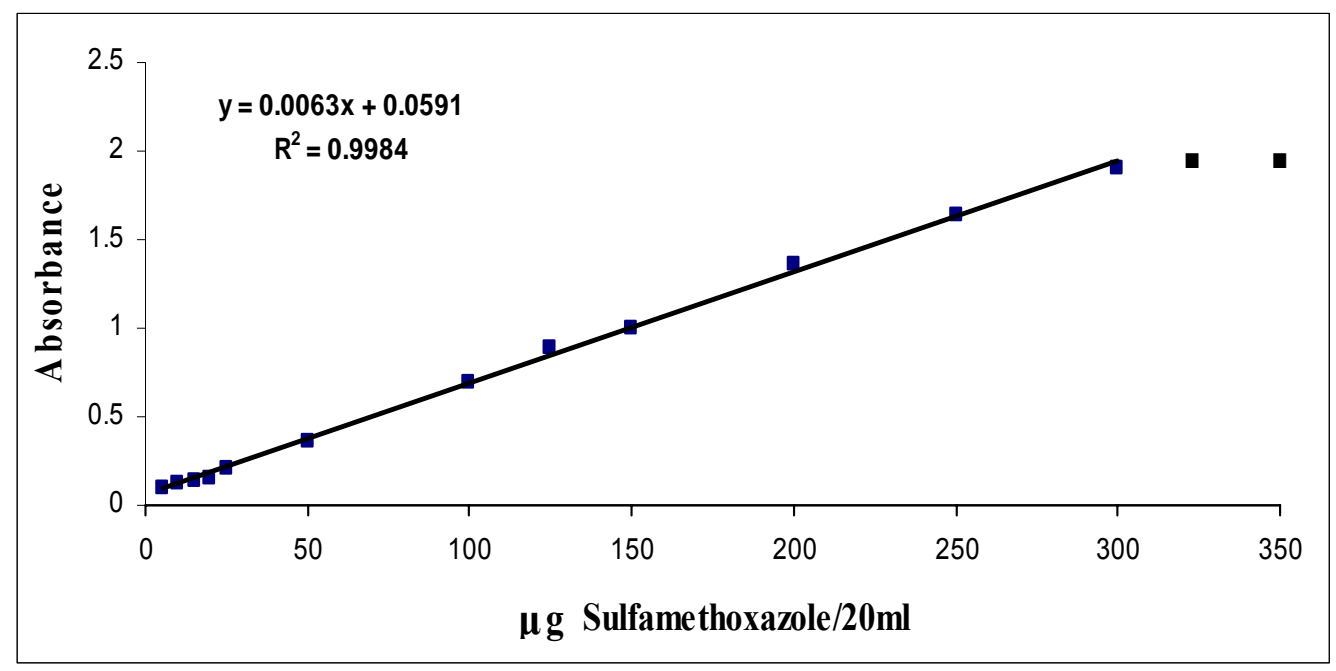

Fig. 6: Calibration curve for SMX determination.

Higher concentrations show a negative deviation from Beer's law. The apparent molar absorptivity of the azo dye has been found to be $3.34 \times 10^{4} 1 . \mathrm{mol}^{-1} \cdot \mathrm{cm}^{-1}$.

The reproducibility of the calibration curve is studied by the analysis of three series of solutions (five identical samples for each series) having final SMX concentration of $1,5,12 \mu \mathrm{g}$ $\mathrm{mL}^{-1}$. The results showed a relative standard deviation of $1.1,2.1$ and $1.8 \%$, respectively. The limit of detection ( $\mathrm{LOD}=0.0584 \mu \mathrm{g} / \mathrm{mL}$ ) and the limit of quantification (LOQ $=0.1752 \mu \mathrm{g} / \mathrm{mL}$ ) are 
calculated as $3.3 \mathrm{~s} / \mathrm{b}$ and $10 \mathrm{~s} / \mathrm{b}$, respectively $(\mathrm{ICH}, 2005)$ where $\mathrm{b}$ is the slope of the calibration curve and $\mathrm{s}$ is the standard deviation (SD) of the blank.

\section{Composition of the azo dye}

The stoichiometry of the reaction between the diazotized drug and $\gamma$-resorsolic acid is studied under the established conditions using both continuous variations (Job's method) and molar ratio methods. The results obtained in both methods (Fig. 7) reveal that the azo dye is formed by a 2:1 combining ratio of diazotized SMX to $\gamma$-resorsolic acid.
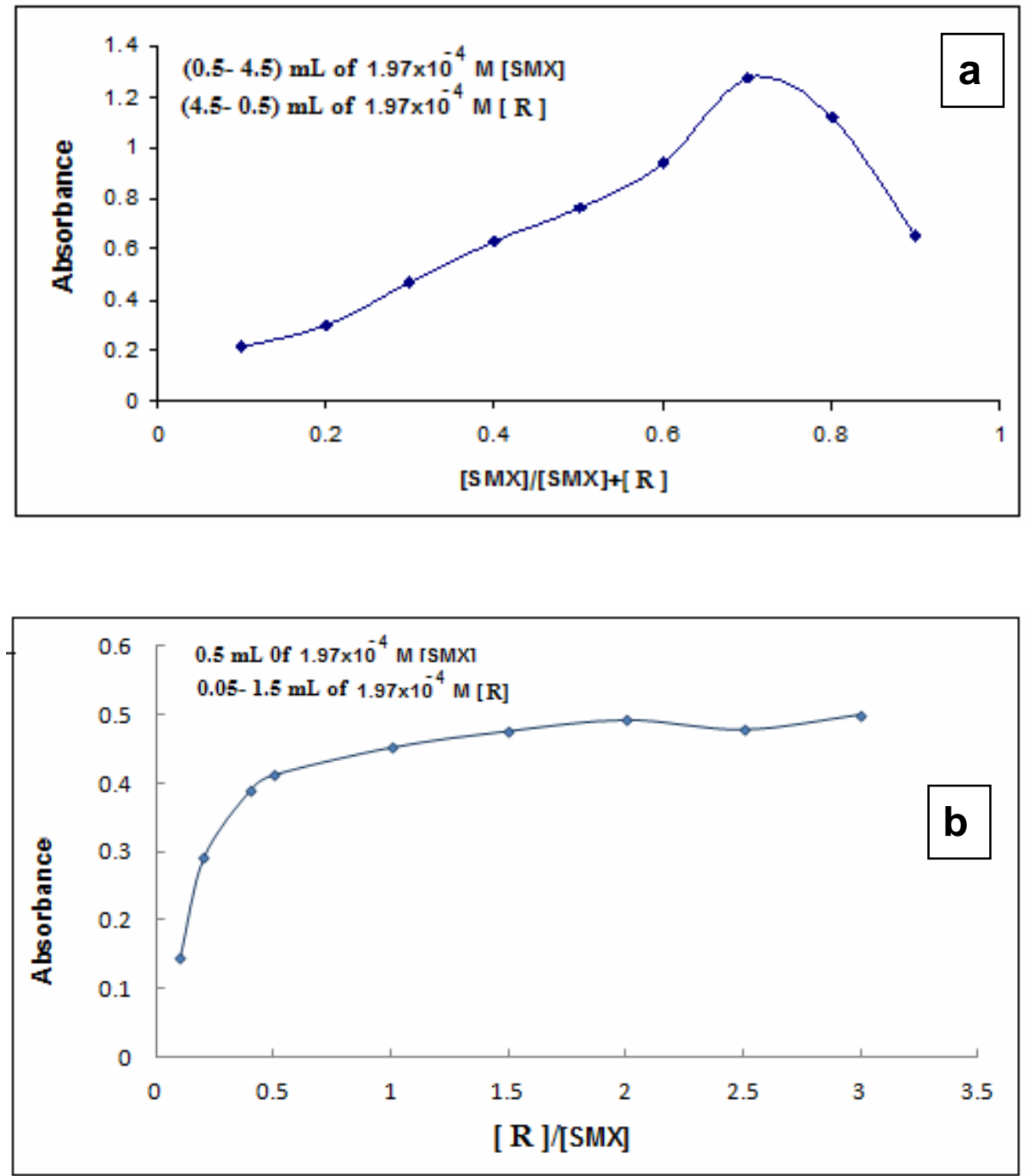

$\mathrm{R}: \gamma$-resorsolic acid

Fig. 7: (a) Continuous variations and (b) molar ratio plots for SMX- $\gamma$-resorsolic acid 
A subsequent reaction scheme (1) based on the above results is as follows:<smiles>Cc1cc(NS(=O)(=O)c2ccc(N)cc2)no1</smiles>

Sulfamethoxazole<smiles>Cc1cc(NS(=O)(=O)c2ccc([N+]#N)cc2)no1</smiles>

Sulfamethoxazole diazonium ion

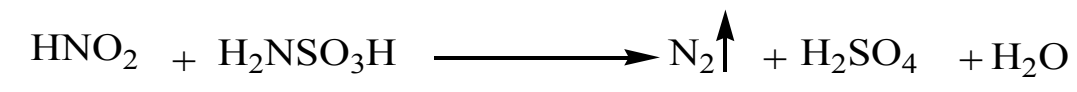<smiles>Cc1cc(NS(=O)(=O)c2ccc([N+]#N)cc2)no1</smiles><smiles>[R]N=Nc1cc(N=N[Y])c(O)c(C(=O)O)c1O</smiles><smiles>[R]#Cc1ccc(S(=O)(=O)Nc2cc(C)on2)cc1</smiles>

Orange azo dye

\section{(Scheme 1)}

In order to test the efficiency and selectivity of the proposed method, the effect of the presence of some common pharmaceutical additives such as starch, glucose, fructose, sorbitol, trimethoprim (TMP) and gum Arabic that are usually present in dosage forms is studied by adding different amounts of foreign substances to $100 \mu \mathrm{g}$ of SMX. The results in (Table 2) indicate that there are no significant interferences produced by these foreign substances on the proposed procedure. 
Table 2: Effect of foreign compounds on assay of SMX

\begin{tabular}{|l|ccc|}
\hline \multirow{2}{*}{ Foreign compound added } & \multicolumn{3}{|c|}{ Recovery $(\mathbf{\%}) *$ of $\mathbf{1 0 0} \boldsymbol{\mu}$ g SMX per $\boldsymbol{\mu g}$ foreign compound } \\
\cline { 2 - 4 } & $\mathbf{1 0 0}$ & $\mathbf{2 5 0}$ & $\mathbf{5 0 0}$ \\
\hline Glucose & 98.9 & 97.4 & 97.0 \\
Fructose & 99.1 & 98.7 & 99.2 \\
Starch & 97.8 & 99.3 & 100.8 \\
Sorbitol & 99.5 & 97.9 & 99.7 \\
TMP & 102.8 & 103.4 & 107.2 \\
Gum Arabic & 99.5 & 98.6 & 99.4 \\
\hline
\end{tabular}

- Average of three determinations

\section{Application of the method}

The proposed method is applied to an analysis of two different pharmaceutical preparations containing SMX (methoprim and cotrim oral suspension) and the performance of the proposed method is assessed by calculating the students' t-test. The results are summarized in (Table 3). For all preparations examined, the assay results of the proposed method are in a good agreement with the declared content. The calculated values for " $t$ " do not exceed the theoretical values of $(t=2.776)$ for $(\mathrm{N}=5)$ at $95 \%$ confidence level (Christian, 2004).

Table 3: Determination of SMX in pharmaceutical preparations

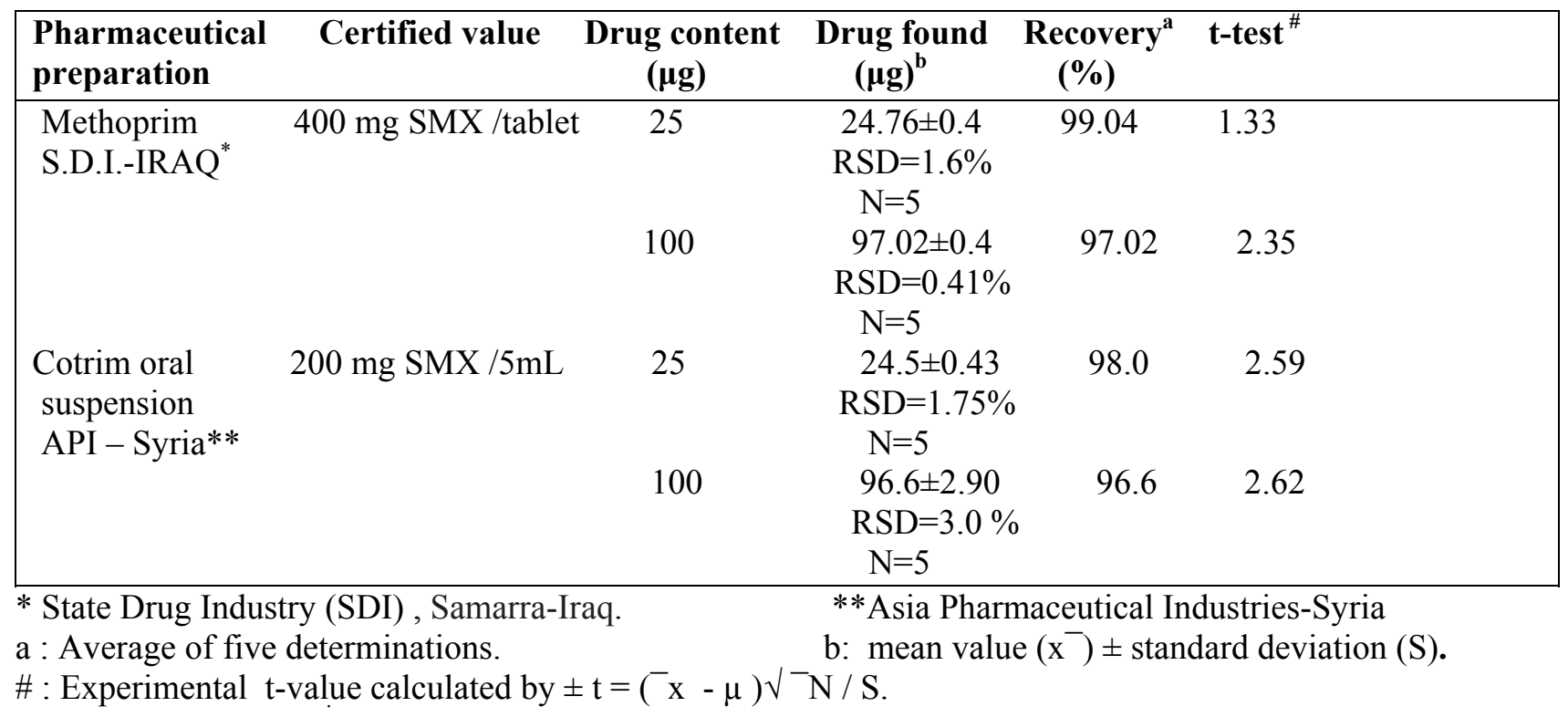

\section{Comparison of the methods}

Table (4) shows a comparison between some of the analytical variables of the present method with that of another literature spectrophotometric methods. 
Table 4: Comparison of the methods

\begin{tabular}{|l|c|c|c|}
\hline \multicolumn{1}{|c|}{ Analytical parameters } & Present method & $\begin{array}{c}\text { Literature method } \\
\text { (Mahmood, 2001) }\end{array}$ & $\begin{array}{c}\text { Literature method } \\
\text { (Obed-Agha, 2010) }\end{array}$ \\
\hline $\mathrm{pH}$ & 12.02 & 11.9 & 11.28 \\
$\lambda$ max $(\mathrm{nm})$ & 432 & 416 & 435 \\
Reagent & $\gamma$-Resorsolic acid & Phloroglucinol & Pyridoxine.HCl \\
Beer's law range (ppm) & $0.25-15$ & $0.4-4$ & $0.2-12$ \\
Molar absorptivity $_{\left(1 . \mathrm{mol}^{-1} . \mathrm{cm}^{-1}\right)}$ ( $) .48 \times 10^{4}$ & $4.9 \times 10^{4}$ & $2.5 \times 10^{4}$ \\
$\mathrm{RSD}(\%)$ & \pm 1.6 to \pm 3.0 & \pm 0.02 to \pm 2.4 & $<3$ \\
Stability of the color $(\mathrm{min})$ & 60 & 15 & 60 \\
Color of the dye & Orange & Yellow & Orange \\
Application & Tablet and oral & Tablet and oral & Tablet and oral \\
& suspension & suspension & suspension \\
\hline
\end{tabular}

The results in the above table indicate that the suggested method is sensitive and accurate.

\section{CONCLUSIONS}

The developed spectrophotometric method for the assay of SMX is simple, sensitive, selective, and inexpensive and exhibits a fair degree of precision and accuracy. Beer's law is obeyed over the concentration range of 5-300 $\mu \mathrm{g} / 20 \mathrm{~mL}$ with an apparent molar absorptivity of $3.34 \times 10^{4}$ $1 . \mathrm{mol}^{-1} . \mathrm{cm}^{-1}$. The method does not involve any critical reaction condition and can be compared favorably with other existing methods. The proposed method can serve as an alternative method for the analysis of SMX in its pharmaceutical formulations (tablets and oral suspension).

\section{REFERENCES}

Al-Attas, A.S. (2003). Charge transfer complex formation in spectrophotometric and conductometric determination of some sulfonamides. J. Saudi Pharm., 11,141-145.

Alatas, F.; Wulansari, D. (2008). The development and validation spectrophotometric method for simultaneous determination sulphamethoxazole and trimetoprim in tablet by continuous wavelet transform. Proceeding of The International Seminar on Chemistry, Jatinangor, 30-31, October, pp. 389-392.

Bedor, C.D.; Concalves, M.; Ferreira, L. M.; Sousa, E.C.; Menezes L.A.; Oliveira, J.E.; Santana, P.D. (2008). Simultaneous determination of sulphamethoxazole and trimethoprime in biological fluids of high-throughput analysis: Comparison of HPLC with ultraviolt and tandem mass spectrophotometric detection. J. Chromatogr. B., 863(1), 46-54.

Boiko, M.; Vrublevska, T.; Korkuna, O.; Teslyar, G. (2011). Application of sulphanilamides disazo dyes with Tropaeolin $\mathrm{O}$ for simple, rapid and sensitive spectrophotometric assay of medicines. Spectrochimica Acta Part A: Molecular and Biomolecular Spectroscopy, 79(2), 325-331.

British Pharmacopoeia on CD-ROM (2001). "The Stationery Office Ltd". London. 3rd edn. Christian, G.D. (2004). "Analytical Chemistry". 6th edn. John Wiley and Sons, Inc., New York, pp. 90-94.

Givianrad, M.H.; Mohagheghian, M. (2012). Net analyst signal standard addition method for simultaneous determination of sulphamethoxazole and trimethoprime in pharmaceutical formulation and biological fluids. J. Chem., 9(2), 680-692.

Givianrad, M.H.; Saber-Tehrani, M.; Zarin, S. (2013). Genetic algorithm-based wavelength selection in multicomponent spectrophotometric determinations by partial least square regression: application to a sulphamethoxazole and trimethoprim mixture in bovine milk. $J$. Serb. Chem. Soc., 78(4), 555-564. 
International Conference on Harmonization (2005). " ICH Harmonized Tripartite Guideline: Validation of Analytical Procedures Text and Methodology, Q2 (R1)". Current Step 4 Version, pp.11-13.

Injac, R.; Kac, J.; Katarina, K.R.; Strukelj, B. (2008). "Optimal conditions for extraction and simultaneous determination of sulphamethoxazole and trimethoprim in pharmaceuticals by micellar lectrokinetic capillary chromatography. J. Food. Drug Anal., 16(1),18-25.

Joseph, R.; Kumar, K.G. (2010). Differential pulse voltammetric determination and catalytic oxidation of sulphamethoxazole using [5,10, 15,20-tetrakis(3-methoxy-4-hydroxy phenyl ) prophyrinato] $\mathrm{Cu}(\mathrm{II})$ modified carbon paste sensor. Drug Test and Analysis, 2(6), 278-283.

.Katzung, B.G. (2007). "Basic and Clinical Pharmacology". 10th edn., McGraw-Hill, Inc., New York, pp. 1061.

Mahmood, Z.T.S. (2001). Spectrophotometric determination of sulfa drugs sulfame-thoxazole and sulfacetamid. M.Sc. Thesis., Mosul University.

Mitscher, L.A. (2002). "Antibiotics and Antimicrobial Agents". in Foye's Principles of Medicinal Chemistry (William D.A.; Lemke T. L.), 5th edn., New York, 819 p.

Nagaragia, P.; Naik, S.D.; Shrestha, A.K.; Shivakumar, A. (2007). A sensitive spectrophotometric method for the determination of sulfonamides in pharmaceutical preparation . Acta Pharm., 57(3), 333-342.

Nagaraja, P.; Yathirajan, H.S.; Raju, C.R.; Vasantha, R.A.; Nagendra, P.; Kumar, M.S.H. (2003). 3-Aminophenol as a novel coupling agent for the spectrophotometric determination of sulfonamide derivatives. II Farmaco., 58(12), 1295-1300.

Obed-Agha, A.N.A. (2010). Development of spectrophotometric kinetic and chroma-tographic methods for determination of some drug compounds and aromatic imines. Ph. D. Thesis, Mosul University.

Othman, N.S. (2005). Spectrophotometric determination of some sulfonamides in aqueous solution via azo-dye formation reaction. J. Educ. Sci., 17, 32-39.

Petri, Jr.W.A. (2001). "Antimicrobial Agents". In Goodman and Gilman's Pharm-acological Basis of Therapeutics (Eds. J.G. Hardman and Lee E. Limbird), 10th ed. McGraw-Hill, USA, pp. 1171-1188.

Sabriye, P.O.; Yucel, S.; Guleren, A. (2011). Determination of sulphamethoxazole in pharmaceutical formulations by flow injection system/HPLC with potentiometric detection using polypyrrole electrode. J. Braz. Chem. Soc., 22(11), 2171-2177.

Salema, A.A.; Mossab, H.A.; Barsoumb, B.N. (2006). Application of nuclear magnetic resonance spectroscopy for quantitative analysis of miconazole,Metron- idazole and sulphamethoxazole in pharmaceutical and urine samples. J. Pharm. Biomed. Anal.,41(2), 654-661.

Shamsa, F.; Amani, L. (2006). Determination of sulphamethoxazole and trimethoprime in pharmaceuticals by Visible and UV spectrophotometry. Iran. J. Pharm.Res., 1, 31-36.

Siddappa, K.; Mahesh, T.; Mallikarjun, M.; Mallikarjun, K. (2011). Spectropho-tometric methods for the determination of sulphamethoxazole by a Schiff's base reaction in pure and pharmaceutical dosage forms. J. Pharm. Res., 4(2), 308 -391.

Sinan, R.; Al-Uzri, W.A. (2011). "Spectrophotometric method for determination of sulphamethoxazole in pharmaceutical preparations bydiazotization-coupling Reaction. J. AlNahrain University, 14(3), 9-16.

Souza, C.D.; Braga, O.C.; Vieira, I.C. (2008). Electroanalytical determination of sulfadiazine and sulphamethoxazole in pharmceuticals using a boron-doped diamond electrode. Sen. Actu. B: Chemical, 135(1), 66-73.

Vijaya Raja, G.; Sekaran, C.B.; Sivakumari, P.; Mahesh, P.V.S. (2008). "Simple and rapid methods for the analysis of sulphonamide bacteriostatic antibiotic in dosage forms. Oriental J. Chem., 24(3), 1021-1024.

Upadhyay, K.; Asthana, A.; Tiwari, N. (2012). Solid Phase Extractive spectrophotom-etric determination of some sulfa drugs. Asian J. Pharma. Clini. Res., 5(2), 222-226. 